\title{
Detection of natural prevalence and infection of ixodid ticks with Theileria equi in hilly equines of Palam valley (I ndia)
}

\author{
Prateek Kashyap ${ }^{1}$, Aman D. Moudgil² and Pallavi ${ }^{3}$
}

1. ERA and Brooke India, Equine Welfare Unit, Palampur, Kangra, Himachal Pradesh, India; 2. Department of Veterinary Parasitology, College of Veterinary Science, Guru Angad Dev Veterinary \& Animal Sciences University, Ludhiana, Punjab, India; 3. Division of Veterinary Public Health, Indian Veterinary Research Institute, Izatnagar, Bareilly, Uttar Pradesh, India. Corresponding author: Prateek Kashyap, email: prateekpandit0871@gmail.com, ADM: moudgil.aman@gmail.com, P: upadhyayapallavi.31@gmail.com

Received: 01-06-2014, Revised: 22-07-2014, Accepted: 31-07-2014. Published Online: 06-09-2014

doi: 10.14202/vetworld.2014.652-655. How to cite this article: Kashyap P, Moudgil AD, Pallavi (2014) Detection of natural prevalence and infection of ixodid ticks with Theileria equi in hilly equines of Palam valley (India), Veterinary World 7(9): 652-655.

\begin{abstract}
Aim: The aim was to study the prevalence of tick infestation in equines of Palam valley and specific detection of Theileria equi infection in tick samples with nested polymerase chain reaction (PCR) based assay.
\end{abstract}

Materials and Methods: In order to study the prevalence of ixodid tick population in hilly equines and their potential role in the transmission of $T$. equi, a total of 74 ticks were collected from apparently healthy equines, which were then processed and identified by classical parasitological technique. The molecular techniques (nested PCR) were applied for identification of infection of T. equi.

Results: The ticks $(\mathrm{n}=74)$ collected from apparently healthy equines belonged mainly to three different species, of which 42 (56.75\%) were Rhipicephalus microplus, whereas 16 (21.62\%) were of Hyalomma species and 16 (21.62\%) were of Hemaphysalis species. A total of 21 (30\%) ticks were recovered from male and 53 (75.7\%) from female equines. Adult equines harbored $94.6 \%(n=70)$ when compared to $5.4 \%(n=4)$ harbored by young ones. On nested PCR amplification an amplicon of 665 bp size specific for $T$. equi was detected in 6.75\% (5/74) ticks (in 7.5\% ticks recovered from a female and $4.7 \%$ from male equines).

Conclusion: Nested PCR assay resulted in significantly higher efficacy of detection of the parasite in ticks. These results clearly demonstrate the presence of equine theileriosis in hilly northern state of the country and potential roles of ticks (R. microplus, Haemaphysalis and Hyalomma species) in its transmission.

Keywords: equines, Himachal Pradesh, nested polymerase chain reaction, Theileria equi

\section{I ntroduction}

The hilly equines, especially ponies and donkeys, play a pivotal role in the lives of the people of the hilly terrains as being used as draught and pack animals [1]. Equine piroplasmosis is important tick borne disease condition caused by large form of Babesia species i.e. Babesia caballi and a Theileria species i.e. Theileria equi [2]. The hazardous disease entity is ubiquitous in distribution [3] and is responsible for morbidity and mortality of horses worldwide. The disease entity rendered by these haemoprotozoans is either peracute, acute, subacute and chronic depending upon the inoculums of the infective dose and course of the disease followed. The peracute forms are observed in the foals following the in-utero infection [4].

The chronic disease condition prevails in endemic areas, where the affected equines are apparently healthy without overt signs of the disease condition, but overexertion and excessive stress leads to subclinical manifestation [5].

Copyright: The authors. This article is an open access article licensed under the terms of the Creative Commons Attributin License (http:// creative commons.org/licenses/by/2.0) which permits unrestricted use, distribution and reproduction in any medium, provided the work is properly cited.
The diagnosis of the disease condition relies on serological and molecular techniques associated with clinical signs [6]. Classical parasitological technique involving microscopic examination is only possible in clinically ill equines as parasitemia is often very low to detect in latent and chronic cases [7]. For epidemiological cases involving large areas, serological diagnosis plays a vital role. Various serological tests employed till date for epidemiological studies involve complement fixation test, indirect fluorescence antibody test and enzyme-linked immunosorbent assay [8-10]. However, molecular methods to diagnose the disease condition are more specific and reliable, especially for the detection of carrier animals [11]. Various polymerase chain reaction (PCR) based detection methods targeting ribosomal 18S ribosomal ribonucleic acid (rRNA) sequence, equine merozoites antigen- 1 gene, rhoptry-associated protein 1, and 16S-rRNA have been developed and employed in a recent past [12-15].

The aim of the present study was to determine the prevalence of ixodid tick population in hilly equines and their correlation with the blood samples examination of the animals to determine their potential role in the transmission of $T$. equi. 


\section{Materials and Methods}

\section{Ethical approval}

Prior consent was taken from the owners of the equines for tick collection. Complete care and measures were taken to avoid any accidental injury to the equine while collecting the ticks.

\section{Field study area}

The study was carried out in Palam valley, Kangra district of northern state of India i.e. Himachal Pradesh from $1^{\text {st }}$ August 2013 to $31^{\text {st }}$ December 2013. The district covers an area of $5739 \mathrm{~km}^{2}$. The temperature and annual rainfall of the area is varying and is approximately $2-30^{\circ} \mathrm{C}$ (range) and $1000 \mathrm{~mm}$, respectively. The hilly breed of equine is reared by the residents as draught and pack animals. The age and sex of the sampling population was recorded.

\section{Sampling of the ticks}

A total of 74 apparently healthy equines were selected, which were not exhibiting signs of any disease condition but harbouring ticks. The ticks were recovered and preserved in 70\% alcohol for morphological and molecular studies.

\section{I dentification of ticks}

The species of the collected ticks was identified by studying the characteristics microscopically as per Hoogstraal [16] and Estrada-Pena et al. [17].

\section{Deoxyribonucleic acid (DNA) extraction and PCR}

DNA was extracted from ticks by using the Qiagen DNeasy Blood and Tissue kits (Qiagen, Hilden, Germany) as per manufacturer's protocol. The DNA was finally extracted in $100 \mu \mathrm{l}$ of elution buffer and was kept at $-20^{\circ} \mathrm{C}$ until further use. A nested PCR was conducted using the protocol of Rampersad et al. [15]. One microliter of DNA sample from all 74 ticks was subjected to primary PCR (BeqF1 5'-ttcgttgactgcgcttggcg- 3' and BeqR1 5'-ctaagaagcggaaatgaaa- $3^{\prime}$ ) and amplicons thus obtained were subjected to nested PCR (BeqF 5'-catcgttgcggcttggttgg- 3' and BeqR 5'-ccaagtctcacaccctattt- 3'). The PCR cycle conditions for all primers were $94^{\circ} \mathrm{C}$ for $15 \mathrm{~s}, 57^{\circ} \mathrm{C}$ for $30 \mathrm{~s}, 72^{\circ} \mathrm{C}$ for $60 \mathrm{~s}$ for 30 cycles followed by an extension at $72^{\circ} \mathrm{C}$ for $5 \mathrm{~min}$. The reactions were performed in the presence of $1.5 \mathrm{mM}$ $\mathrm{MgCl}_{2}$. The presence and size of amplified DNA in PCR reactions was determined by gel electrophoresis on a $1.0 \%$ gel. The results were considered as positive if the amplicons obtained were of expected molecular weight i.e. 665 bp. A non-template control i.e. control having no DNA amplicon was also used to rule out any contamination of the products.

\section{Statistical analysis}

Data were analyzed using Win Episcope 2.0 software (College of Medicine and Veterinary Medicine, University of Edinburgh, Scotland) for evaluation of risk factors with 95\% confidence interval (CI).

\section{Results}

Of 74 ticks collected 42 (56.75\%) (95\% $\mathrm{CI}=0.4472-0.6823 \%)$ were Rhipicephalus microplus, whereas 16 (21.62\%) (95\% CI=0.1289-0.3272\%) were of Hyalomma species and 16 (21.62\%) (95\% $\mathrm{CI}=0.1289-0.3272 \%)$ were of Haemaphysalis species. Sex-wise division revealed females equines (71.62\%) (95\% CI=0.5995-0.8150\%) to be heavily infested by ticks as compared to their male counterparts (28.38\%) (95\% CI=0.1850-0.4005\%). The adult equines also showed more tick infestation (94.6\%) (95\% CI=0.8673-0.9851\%) than young ones $(5.4 \%)$ (95\% CI=0.0149-0.1327\%). The details are depicted in Table-1.

On nested PCR amplification an amplicon of 665 bp size specific for T. equi was observed in 6.75\% (5/74) ticks (95\% CI=0.0223-0.1507\%) (Figure-1, Table-2). All the five infected ticks were recovered from five different horses belonging to different areas. Three horses among these five horses also showed presence of $T$. equi in blood samples through nested PCR. Only 4.7\% (1/21) (95\% CI=0.0012-0.2382\%) tick population recovered from apparently healthy male equines showed presence of $T$. equi infection, whereas 7.5\% (3/53) (95\% CI=0.0118-0.1566\%) ticks recovered from female equines revealed the presence of infection. The ticks recovered from young equines showed less infection (2.5\%) (95\% CI=0.0063$0.8059 \%$ ) of $T$. equi when compared to the adults (5.7\%) (95\% CI=0.0158-0.1399\%). However, values of relative risk were higher in case of the ticks recovered from male equines as compared to female equines and in case of young animals when compared to adults.

\section{Discussion}

The maximum number of ticks was recovered from equine adult females as compared to adult males and young animals, which could be due

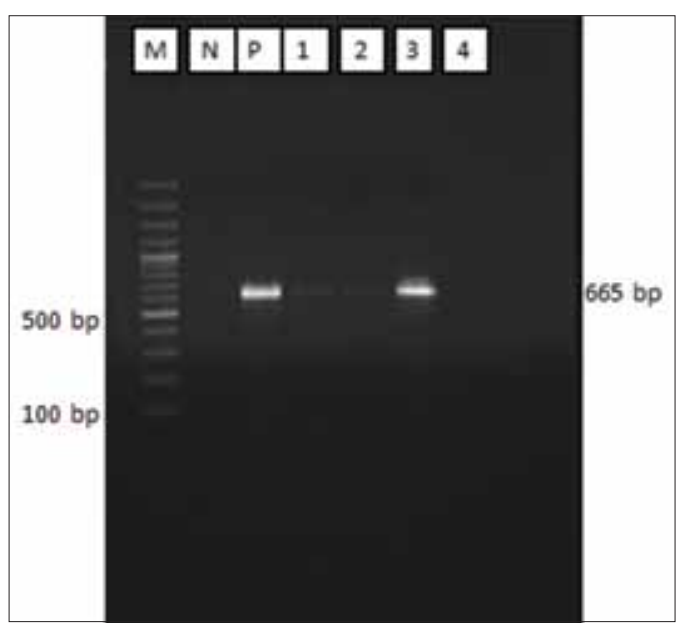

Figure-1: Agarose gel electrophoresis (1.0\%) showing amplicons of $665 \mathrm{bp}$ for Theileria equi. Lane M: $100 \mathrm{bp}$ deoxyribonucleic acid (DNA) ladder/marker; Lane N: Nontemplate control; Lane P: Positive control; Lane 1-4: Tick DNA amplicons. 
Table-1: Prevalence of ticks targeting age and sex of equines.

\begin{tabular}{|c|c|c|c|c|c|}
\hline \multirow[t]{2}{*}{ Equines } & \multicolumn{5}{|c|}{ Species of ticks } \\
\hline & $\begin{array}{l}\text { Rhipicephalus } \\
\text { microplus (\%) }\end{array}$ & $\begin{array}{l}\text { Hemaphysalis } \\
\text { species (\%) }\end{array}$ & $\begin{array}{c}\text { Hyalomma } \\
\text { species (\%) }\end{array}$ & $\begin{array}{l}\text { Total } \\
(\%)\end{array}$ & $\begin{array}{c}\text { Relative risk } \\
(95 \% \mathrm{Cl})\end{array}$ \\
\hline \multicolumn{6}{|l|}{ Sex } \\
\hline Male & $9(12.16)$ & $7(9.45)$ & $5(6.75)$ & $21(28.38)$ & $43(2.653-696.99)$ \\
\hline Female & $33(44.59)$ & $9(12.16)$ & $11(14.86)$ & $53(71.62)^{*}$ & $107(6.729-1701.31)$ \\
\hline Total & $42(56.75) *$ & $16(21.62)$ & $16(21.62)$ & 74 & \\
\hline $\begin{array}{l}\text { Relative risk } \\
(95 \% \mathrm{Cl})\end{array}$ & $85(5.328-1356.05)$ & $33(2.0162-540.117)$ & $33(2.0162-540.117)$ & & \\
\hline \multicolumn{6}{|l|}{ Age } \\
\hline $\begin{array}{l}\text { Young } \\
\text { (<2 years) }\end{array}$ & $3(4.05)$ & 0 & $1(1.35)$ & $4(5.4)$ & $9(0.493-164.258)$ \\
\hline $\begin{array}{l}\text { Adult (more } \\
\text { than } 2 \text { years) }\end{array}$ & $39(52.07)$ & $16(21.62)$ & $15(20.27)$ & $70(94.6)^{*}$ & $141(8.896-2234.91)$ \\
\hline Total & $42(56.75)^{*}$ & $16(21.62)$ & $16(21.62)$ & 74 & \\
\hline $\begin{array}{l}\text { Relative risk } \\
(95 \% \mathrm{Cl})\end{array}$ & $85(5.328-1356.05)$ & $33(2.0162-540.117)$ & $33(2.0162-540.117)$ & & \\
\hline
\end{tabular}

*Factor associated with relatively higher risk, $\mathrm{Cl}=$ Confidence interval, Rhipicephalus microplus=R. microplus

Table-2: PCR amplification targeting T. equi infection in ixodid ticks.

\begin{tabular}{lccc}
\hline Equines & \multicolumn{2}{c}{ PCR targets } \\
\cline { 2 - 4 } & \multicolumn{2}{c}{ Ticks } & $\begin{array}{c}\text { Relative risk } \\
\text { (95\% confidence } \\
\text { interval) (\%) }\end{array}$ \\
\cline { 2 - 4 } & Total & Positive (\%) & $10.2273(0.431-242.32)$ \\
\hline Sex & & & $9.7222(0.512-184.39)$ \\
$\quad$ Male & 21 & $1(4.7) *$ & $10.3125(0.580-183.33)$ \\
$\quad$ Female & 53 & $3(7.5)$ & $45(2.089-969.36)$ \\
Total & 74 & $5(6.75)$ & $9.5070(0.521-173.43)$ \\
Age & 4 & $1(2.5) *$ & $10.3125(0.580-183.33)$ \\
$\quad$ Young (<2 years) & 70 & $4(5.7)$ & $5(6.75)$ \\
$\quad$ Adult (more than 2 years) & 74 & &
\end{tabular}

*Factor associated with relatively higher risk, $\mathrm{PCR}=$ Polymerase chain reaction, Theileria equi=T. equi

to partial selection of the female equines over their male counterparts due to their significant reproductive and draught potential $[18,19]$. The conditions in hilly areas are less favorable for the development of ticks [1], thus the prevalence observed in the present study could be attributed to trade and immigration of equines to the study area from the different plain zones of the country, contributing to addition of ticks and the diseases, transmitted by these vectors to the native hilly equine population. The scarcity of literature revealing any previous study targeting tick population in Palam valley has restricted any comparison about the prevalence of ixodid tick vectors.

As in case of PCR, especially nested PCR there are chances of contamination resulting in false positive results due to contaminating DNA [15]. Thus, at every instance a non-template (without amplicons) control was used to establish the authenticity of the positive results, indicating that they had not been generated as a result of contaminating DNA $[20,21]$.

The presence of positive cases in apparently healthy equines in this part of India also raises concern about the availability and prevalence of the parasite, which could be attributed to the introduction of the parasite along with the ticks and horses brought to these hilly areas from the other parts of India. The large number of clinically healthy animals testing positive suggest that disease may have precipitated from a sub-clinical infection and has resulted from certain adverse factors such as strenuous exercise [22-24]. The comparatively higher infection encountered in ticks recovered from the female when compared to male equines could be due to higher number of tick samples collected from female equines resulting in increased probability of infected ticks recovery. The values of the relative risk were high in case of the ticks recovered from male equines as compared to female equines and from young equines as compared to adults, which could be due to lesser number of ticks retrieved from male and young equines when compared to their counterparts and hence probability of infected ticks and relative risk of infection in these animals increases. Thus, ticks play as an important role as vectors of fatally infective diseases to healthy animals [25].

\section{Conclusion}

Ticks play an important role as vector of fatal diseases of equines. The prevalence study targeting tick population can help in formulating the control measures against them and the suspected diseases transmitted by them. Based on the results of the present 
study, nested PCR could be assumed to be a useful tool for the detection of hemoprotozoans i.e. T. equi especially in case of apparently healthy animals, which could act as carriers or possess latent infection.

\section{Authors' Contribution}

PK prepared the study outline and carried out collection of samples. ADM carried out classical parasitological work related to identification of ticks and $\mathrm{P}$ performed the molecular work. All the authors were involved in review of literature and manuscript preparation. All authors read and approved the final manuscript.

\section{Competing I nterests} interests.

The authors declare that they have no competing

\section{Acknowledgments}

Authors are thankful to ERA and Brooke India, Equine Welfare Unit, Palampur, Kangra, Himachal Pradesh for providing the funds to carry out the research and to its staff members of for helping in collection of ticks from different parts of Palam Valley.

\section{References}

1. Kumar, S., Kumar, R. and Sugimoto, C. (2009) A perspective on Theileria equi in donkeys. Jpn. J. Vet. Res., 56(4): 171-180.

2. Rothschild, C.M. and Knowles, D.P. (2007) Equine piroplasmosis. In: Equine Infectious Diseases. Saunders Elsevier, St. Louis, MO. p465-473.

3. De Waal, D.T. (1992) Equine piroplasmosis: A review. Br. Vet. J., 148: 6-14.

4. Abedi, B., Razmi, G., Seifi, H. and Naghibi, A. (2014) Molecular and serological detection of Theileria equi and Babesia caballi infection in horses and ixodid ticks in Iran. Ticks Tick Borne Dis., 5(3): 239-244.

5. Takeet, M., Adeleye, A., Adebayo, O.O. and Akande, F. (2009) Haematology and serum biochemical alteration in stress induced equine theileriosis. A case report. Sci. World J., 4: 19-21.

6. Jaffer, O., Abdishakur, F., Hakimuddin, F., Riya, A., Wernery, U. and Schuster, R.K. (2010) A comparative study of serological tests and PCR for the diagnosis of equine piroplasmosis. Parasitol. Res., 106(3): 709-713.

7. Mujica, F.F., Perrone, T., Forlano, M., Coronado, A., Melendez, R.D., Barrios, N., Alvarez, R., and Granda, F. (2011) Serological prevalence of Babesia caballi and Theileria equi in horses of Lara State, Venezuela. Vet. Parasitol., 178(1-2): 180-183.

8. Abutarbush, S.M., Alqawasmeh, D.M., Mukbel, R.M. and Al-Majali, A.M. (2012) Equine babesiosis: Seroprevalence, risk factors and comparison of different diagnostic methods in Jordan. Transbound Emerg. Dis., 59(1): 72-78.

9. García-Bocanegra, I., Arenas-Montes, A., Hernández, E., Adaszek, L., Carbonero, A., Almería, S., JaénTéllez, J.A., Gutiérrez-Palomino, P., and Arenas, A. (2013) Seroprevalence and risk factors associated with Babesia caballi and Theileria equi infection in equids. Vet. J., 19(2)5: 172-178.
10. Farkas, R., Tánczos, B., Gyurkovszky, M., Földvári, G., Solymosi, N., Edelhofer, R. and Hornok, S. (2013) Serological and molecular detection of Theileria equi infection in horses in Hungary. Vet. Parasitol., 192(1-3): 143-148.

11. Bose, R., Jorgensen, W.K., Dalgliesh, R.J., Friedhoff, K.T. and De Vos, A.J. (1995) Current state and future trends in the diagnosis of babesiosis. Vet. Parasitol., 57(1-3): 61-74.

12. Bahiruddin, J.B., Camma, C. and Rebelo, E. (1999) Molecular detection of Babesia equi and Babesia caballi in horse blood by PCR amplification of part of the 16S rRNA gene. Vet. Parasitol., 84(1-2): 75-83.

13. Nicolaiewsky, T.B., Richter, M.F., Lunge, V.R., Cunha, C.W., Delagostin, O., Ikuta, N., Fonseca, A.S., Silva, S.S. and Ozaki, L.S. (2001) Detection of Babesia equi (Laveran, 1901) by nested polymerase chain reaction. Vet. Parasitol., 101(1): 9-21.

14. Battsetseg, B., Lucero, S., Xuan, X., Claveria, F.G., Inoue, N., Alhassan, A., Kanno, T., Igarashi, I., Nagasawa, H., Mikami, T. and Fujisaki, K. (2002) Detection of natural infection of Boophilus microplus with Babesia equi and Babesia caballi in Brazilian horses using nested polymerase chain reaction. Vet. Parasitol., 22: 351-357.

15. Rampersad, J., Cesar, E., Campell, M.D., Samlal, M. and Ammons, D. (2003) A field eval-uation of PCR for the routine detection of Babesia equi in horses. Vet. Parasitol., 114(2): 81-87.

16. Hoogstraal, H. (1956) In: African Ixodoidea. Ticks of the Sudan, Vol. 1. US Naval Medical Research Unit No. 3, Cairo, Egypt.

17. Estrada-Pena, A., Bouattour, A., Camicas, J.L. and Walker, A.R. (2004) In: Ticks of Domestic Animals in the Mediterranean Region, a Guide to Identification of Species. Bioscience Reports, UK.

18. Al-Saad, K.M. (2009) Acute babesiosis in foals. J. Anim. Vet. Adv., 8: 2585-2589.

19. Baldani, C.D., Nakaghi, A.C., Machado, R.Z. (2010) Occurrence of Theileria equi in horses raised in the Jaboticabal microregion, São Paulo State, Brazil. Rev. Bras. Parasitol. Vet., 19: 228-232.

20. Lori, A., Gabrielli, S., Calderini, P., Moretti, A., Pietrobelli, M., Tampieri, M.P., Galuppi, R. and Cancrini, G. (2010) Tick reservoirs for piroplasms in central and Northern Italy. Vet. Parasitol., 170(3-4): 291-296.

21. Moretti, A., Mangili, V., Salvatori, R., Maresca, C., Scoccia, E., Torina, A., Moretta, I., Gabrielli, S., Tampieri, M.P. and Pietrobelli, M. (2010) Prevalence and diagnosis of Babesia and Theileria infections in horses in Italy: A preliminary study. Vet. J., 184(3): 346-350.

22. Alanazi, A.D., Alyousif, M.S. and Hassieb, M.M. (2012) Seroprevalence study on Theileria equi and Babesia caballi antibodies in horses from central province of Saudi Arabia. J. Parasitol., 98(5): 1015-1017.

23. Steinman, A., Zimmerman, T., Klement, E., Lensky, I.M., Berlin, D., Gottlieb, Y. and Baneth, G. (2012) Demographic and environmental risk factors for infection by Theileria equi in 590 horses in Israel. Vet. Parasitol., 187(3-4): 558-562.

24. Hailat, N.Q., Lafi, S.Q., Al-Darraji, A.M. and Al-Ani, F.K. (1997) Equine babesiosis associated with strenuous exercise: Clinical and pathological studies in Jordan. Vet. Parasitol., 69(1-2): 1-8.

25. Scoles, G.A., Hutcheson, H.J., Schlater, J.L., Hennager, S.G. and Knowles, D.P. (2011) Equine piroplasmosis associated with Amblyomma cajennense ticks, Texas, USA. Emerg. Infect. Dis., 17(10): 1903-1905. 